\title{
A Legal History of International Reparations
}

\author{
By \\ Richard M. Buxbaum*
}

\section{INTRODUCTION}

We have witnessed an increasing interest in reparations over the past decade, an interest derived from episodes both domestic and international, ranging historically from the legacy of slavery in the United States to events occurring these past ten years in Iraq and the Horn of Africa. ${ }^{1}$ One principal event, which not only generated most of the reparations activities and discourse of the past half-century but which has also been the subject of much of the litigation and negotiations of the most recent period, is the German payment of reparations arising out of World War II atrocities. ${ }^{2}$

German reparations have also been at the center of the single most critical and controversial evolution of public international law in the past century; namely, the movement from state-centered to societal- and individual-centered rights and obligations. This evolution has its substantive focus in the field of international human rights, and its procedural focus in the increasingly contested primacy of state reparations over direct individual claims for compensation and restitution. Both issues arose in and are illuminated by the history of German reparations and compensation or restitution payments.

* Jackson H. Ralston Professor of International Law, School of Law (Boalt Hall), University of California at Berkeley. My thanks to a number of research assistants, in particular Lisa Pfitzner, Sonya Hymer, Nilima Muttana, and Rachel Anderson; my thanks also to Wiebke Buxbaum, David Caron, and Gerald Feldman for critical reading of the manuscript and good advice. Even more than in the usual case, it should be emphasized that errors of fact and interpretation are my own. Some disclaimers and disclosures: these are my personal views; they do not derive from and should not be attributed to the Property Commission of the German Foundation for Remembrance, Responsibility, and the Future, of which I am the U.S. member, to its staff, or to the appointing authority (U.S. Department of State). For personal reasons, I have been interested in the issues discussed herein and have had some peripheral engagement with them for many years; more recently, I was a consultant to counsel representing some of the defendants in the U.S. litigation that was settled by the United States-Germany agreement leading to the creation of the mentioned Foundation (see n. 13 infra).

1. For a general overview along with some case studies, see ELEAZAR BARKAN, THE GUILT OF NATIONS (New York 2000). The litigation history involving private-sector, largely corporate defendants is briefly traced in Anita Ramasastry, Corporate Complicity from Nuremberg to Rangoon, 20 BERKELEY J. INT'L L. 9 I (2002).

2. See Michael J. Bazyler \& Amber L. Fitzgerald, Trading with the Enemy: Holocaust Restitution, the United States Government, and American Industry, 28 BROOK. J. INT'L L. 683 (2003) (detailing this litigation history) 
This article, the first part of a larger project, is concerned with the history of these issues in the early postwar period, during which time the interstate form of reparations occupied center stage and the direct form of victim compensation and restitution, now established, was only beginning to be formulated. While this article does not purport to contribute directly to the doctrinal question of whether the individual is a rights-bearing subject of international law, it does illuminate the context within which this development first became visible. Given the focus of the following discussion on the wartime and early postwar period, from the Yalta Conference of 1943 to the Paris Reparation Agreement of January 1946, the discussion's relevance to that doctrinal question is derived from placement of the Paris Agreement in a broader framework, one providing the apparent primacy of interstate reparation that the Paris Agreement is often read to have established.

The current salience of the question of the individual as a rights-bearing subject of international law is well illustrated by two important cases that are phrased in the modern terminology of jus cogens, or peremptory norms of public international law. These cases exemplify the potential migration of those peremptory norms from their original location in the law of treaties to their debatable use in municipal litigation. ${ }^{3}$ In 1994, Princz v. Federal Republic of Ger$m a n y^{4}$ held that even claims based on these peremptory norms (in this case, genocide and crimes against humanity) could not be brought in U.S. courts without the foreign sovereign's consent. Nine years later, the German Supreme Court decided a parallel case, ${ }^{5}$ holding that the state-centered concept of international law still prevalent during the war period precluded an individual from bringing suit against the sovereign. On this basis, the court denied German recognition and enforcement of a Greek judgment in a private action against Germany on ordre public grounds. ${ }^{6}$

3. This distinction and development is well-explained in Erika de Wet, The Prohibition of Torture as an International Norm of jus cogens and Its Implications for National and Customary Law, 15 EUR. J. INT'L L. 97 (2004).

4. 26 F.3d 1166 (D.C. Cir. 1994), cert. denied., 513 U.S. 1121 (1995); see also Sampson v. Federal Republic of Germany, 250 F.3d 1145 (7th Cir. 2001); Smith v. Socialist People's Libyan Arab Jamahiriya, 101 F.3d 239 (2d Cir. 1996); Siderman de Blake v. Republic of Argentina, 965 F.2d 699 (6th Cir. 1992).

5. Decision of the Bundesgerichtshof (Federal Supreme Court), June 26, 2003 ("Distomo"), 115 BGHZ 279 (2004); for an English translation, see Elizabeth C. Handl, German Federal Supreme Court: The Distomo Massacre Case (Greek Citizens v. F.R.G.), 42 I.L.M. 1030 (2003). This case is also discussed in Sabine Pitthoff, Compensation Claims for Human Rights Breaches Committed by German Armed Forces Abroad During the Second World War: Federal Court of Justice Hands Down Decision in the Distomo Case, 5 GERMAN L.J. I (January 2004).

6. Decision of the Areios Pagos (Court of Cassation) 137/97, May 4, 2000; German translation in 33 Kritische Justiz $472(2000)$. See also von Hein, The Law Applicable to Governmental Liability for Violations of Human Rights in World War II, 3 Y.B. PRIVATE L. 185 (2001); Maria Gavouneli \& Ilias Bentekas, Note, 95 AM. J. INT'L L. 198 (2001). In a later case seeking execution on that judgment, however, a specially convened session of the court ruled that the distinct doctrine of sovereign immunity against execution of judgments prevented that step. See Court of Cassation, No. 6/2002, June 28, 2002 ; Maria Panezi, Sovereign Immunity and Violation of Jus Cogens Norms, 56 REVUE HELLENIQUE DE DROIT INT'L 199 (2003) (providing a summary and critique of that case). In 
In this pair of cases, the two principal nations involved in the postwar German reparations process reaffirmed that states remain the primary, if not exclusive, actors, at least so far as litigation concerning the earlier era's version of public international law is concerned. Furthermore, the exclusivity of this remedy continued to govern later efforts of non-state parties to claim direct rights of compensation for injuries arising out of behavior that not only now, but even at the time of its commission, would have been characterized as a basic violation of the law of nations.

At the same time, these types of rulings, issued fairly consistently though infrequently over the past half-century, have not withstood domestic political pressure to provide compensation to victims of persecution. While these rulings may state the law on the books, on the whole they do not fully reflect the law in action. This article addresses the underlying historical basis for this pattern.

Postwar claims against Germany blurred traditional boundaries between public international law and domestic constitutional law. They also provided an important impetus, though not the only one, for the evolution of traditional statecentered international law to a system of international-relations law that now includes non-state actors as both active and passive subjects of the law. To explore these two cases in the European reparations context, five strands of thought - three general and two specific to Germany-need to be separated and then rewoven. One: whether state claims for reparations encompass compensation for particularized harms suffered by a subject of the claimant state. Two: may that subject make a claim directly against the other state? Three: do claims, either by the state or its subjects, encompass compensation for harms caused by non-state actors of the offending state? This issue also raises the question of whether those private actors may be sued directly, either by the claimant state or, more typically, by the victim-subject of that state. Four (an issue historically specific to World War II): the temporary disappearance of Germany as a sovereign state actor and the substitution of the Occupying Powers as that sovereign. Five (again, historically specific): the nature of the atrocities committed by the Third Reich against both its own persecuted subjects and those of other states that was qualitatively different from those known to modern warfare.

The last two issues bear on the postwar influence of public international law on the constitutional and administrative law of the recreated Germany. They also at least indirectly bear, however, on the converse situation-the way

the meantime the Greek complainants filed an appeal (against the original refusal of execution by the Ministry of Justice) with the European Court of Human Rights, alleging this denial of justice was a violation of the European Human Rights Convention. However, they were rebuffed by that court. Kalogeropoulou et al. v. Greece \& Germany, Admissibility Decision of 12 December 2002, available at $\mathrm{http}: / / \mathrm{cmiskp}$.echr.coe.int/tkp 197/view.asp?item=1 \&portal=hbkm\&action=prof\&highlight= kalogeropoulou\&sessionid=4135968\&skin=hudoc-en. See Kerstin Bartsch and Björn Elberling, Jus Cogens vs. State Immunity, Round Two: The Decision of the European Court of Human Rights in Kalogeropoulou et al. v. Greece and Germany, 4 GERMAN L.J. No. 5 (2003). For a broader context see Andrea Bianchi, L'immunité des Etats et les violations graves des droits de l'homme: la function de l'interprète dans la determination du droit international, 108 REV. GÉN'L DROIT INT'L PUBLIC 63 (2004). 
and extent to which the substantive law of state responsibility has evolved since World War II. The wartime behavior of the German Reich was a significant influence on the postwar substantive expansion of traditional public international law through its development of the jus cogens concept, which it developed by contesting the traditional immunity of a foreign sovereign ${ }^{7}$ from suit in the municipal courts of other states when particularly abhorrent state behavior is involved. $^{8}$ In addition, it influenced the procedural expansion of international law from a set of norms bearing exclusively on interstate relationships to a vehicle for permitting non-state actors, including individual human beings, to act as subjects of public international law capable of asserting claims against their own as well as other nations. ${ }^{9}$

While all of these issues are addressed in the discussion that follows, only the evolution of interstate relations in the reparations context (and only the first postwar stage) is covered in detail. ${ }^{10}$ In Part $I$, the traditional concept of reparations is briefly sketched out. Parts II and III describe the wartime and postwar formulation of a reparations policy by the Allies, largely from within the framework of property claims. ${ }^{11}$ The emphasis in those Parts is on elements of the policy that highlight the contradictions between general and exclusively interstate reparations on the one hand, and a policy of restitution that might privilege certain claimant states on the other. ${ }^{12}$ The contradiction between general and particular restitution policies planted seeds of conflicts that resonate to this day.

In related studies I hope to broaden my focus to consider the history of di-

7. In what context and in what forum-politics or law-is a preliminary issue. In this article, 1 focus on the political forum: but, as the text suggests, the judicial forum and the implication that their non-state complainants now may be heard is the subject of most debates.

8. The most contested recent example of that proposition is the cited decision of the Areios Pagos of Greece, supra n. 6. More recently, the Italian Supreme Court (Corte suprema di cassazione), in Ferrini c. Repubblica Federale di Germania, Decision of November 6, 2003, reported in 87 Rivista Diritto Internazionale 539 (2004), following the Distomo decision in a case that also arose out of alleged jus cogens violations occurring on Italian soil during the German occupation. Like Distomo, it limited its use of jus cogens to trump foreign sovereign immunity in situations in which the action complained of occurred in the territory of the forum state. For an evaluation of the decision's significance, see Recent Decisions [Andrea Bianchi], "Ferrini v. Federal Republic of Germany," 99 AM. J. INT'L L. 242 (2005). The French courts, however, have recently confirmed the more traditional position that foreign sovereign immunity trumps at least forced-labor claims, even if the German seizure of such persons took place on French soil. See, e.g., Cour Cass., Bucheron, 108 REV.GÉN'L DR. INT'L PUB. 259 (2004).

9. It also influenced the development of norms permitting private civil actions against individuals and corporations for violation of relevant norms of international law. That development will not be discussed in this article.

10. Other papers, currently in process, intend to continue analyzing the interstate aspect of reparations to the present day as well as to extend the discussion to these other actors and to the role of municipal courts and legislatures.

11. At the interstate level, the intensity and legitimacy of individual expectations of compensation for the loss of life, liberty, and health are only indirectly visible in the espousal of reparations for these delicts by the states to which those individuals owe their allegiance. Individuals' direct claims against the state-perpetrator are another matter, but the tensions between the two forms of redress lie at the center of today's discourses about reparations.

12. Such a policy, privileging restitution, would favor private claimants of property seized by the German occupation regime and now available for return. 
rect compensation awarded for the loss of life, liberty, health, and prospects. This type of compensation was first imposed upon the Western Zones of early postwar Germany by the Occupying Powers and then built into the domestic legislation of the new Federal Republic as an obligation attendant upon its birth. This domestic obligation to the Republic's own persecuted subjects generated similar expectations by similarly persecuted subjects (or former subjects) of the occupied states, and, persisting to the present, resulted in a number of compensation schemes, including the Foundation for Responsibility, Remembrance, and the Future, established by the German government in response to class action litigation in U.S. courts during the latter half of the $1990 \mathrm{~s}^{13}$

The ongoing struggle over these issues during the postwar period calls for a simple periodicization. I suggest five postwar eras, each with its own focus on one of the substantive issues adumbrated above. The first period, the first part of which is the subject of this article, runs from wartime to the establishment of the Federal Republic's formal status in 1949. Its substantive focus, apart from the immediate issue of life support for the variously affected populations, was on reparations in the classic sense: payments of various types to the Allied states. The second period lies between 1950, when discussions about payment of occupation costs and prewar privately-held debt began, and the mid-1960s, when the first satisfaction of interstate reparations had been achieved and a serious statutory effort to compensate the (mostly formerly) German victims of wartime persecution was established. The third period is that of the Ostpolitik, initiated by the first Social-Democratic Chancellor of the Federal Republic, Willy Brandt, and its consequences for new intergovernmental claims. The fourth, roughly the decade of the 1980s, saw a sea change in the position of individuals and social groups vis-à-vis their respective governments, and specifically toward the Federal Republic on the issue of compensation for persecution. This development explains the explosion of claims and expectations during the fifth period-specifically, the period following the collapse of State Socialism and the unification of Germany-more than is commonly appreciated, even if those political transformations also generated their own dynamic in this field.

The recent experiences of a number of international commissions engaged in private-claim settlements over the past decade highlight a common thread running through all of these five stages, and help explain why no repose has been achieved on this question of compensation since 1945. The espousal by

13. Gesetz zur Errichtung einer Stiftung (Erinnerung, Verantwortung und Zukunft), Aug. 2, $2000 \mathrm{BGBl}$. I at 1263, based on the United States-Germany agreement concerning the Foundation "Remembrance, Responsibility and the Future," July 17, 2000, reprinted in 39 I.L.M. 1298 (2000). Its creation and the events leading thereto are discussed by a leading participant in STUART E. EIZENSTAT, IMPERFECT JUSTICE (2003), and by two close observers in JOHN AUTHERS \& RICHARD WOLFFE, THE VICTIM'S FORTUNE (2002). For critical comment, see generally Detlev Vagts \& Peter Murray, Litigating the Nazi Labor Claims: The Path Not Taken, 43 HARV. INT'L L.J. 503 (2002) (creating a record of the settled cases and relevant issues, arguments, and authorities); Libby Adler \& Peer Zumbansen, The Forgetfulness of Noblesse: A Critique of the German Foundation Law Compensating Slave and Forced Laborers of the Third Reich, 39 HARV. J. ON LEGIS. 1 (2002) (identifying numerous flaws with the Foundation Law). 
the state of its own claims for economic loss inherently conflicts with its espousal, as their agent, of claims of particular classes of its subjects. ${ }^{14}$ The dissatisfaction of increasingly empowered private actors with the representation offered them by the state goes far to explain this conflict. ${ }^{15}$ Of course, the gradual increase of subject empowerment is a broader phenomenon than this one component, but the latter was a causal factor, among others, ${ }^{16}$ in the overall changes in state-society relations.

I.

\section{THE PRE-WORLD WAR II CONCEPT OF REPARATIONS}

Until World War I, the payment of reparations by the vanquished state to the victorious state had been one of the many elements of peace negotiations. The issue had no particular moral connotation, and payments were limited by the limited nature of the preceding war. World War I differed from its postWestphalian European predecessors both in its scale and its total involvement of civilian populations. These differences raised the stakes of reparations for the victors $^{17}$ and invited the possibility of justifying higher stakes by reference to moral and political responsibility. ${ }^{18}$ This foreshadowed the reparations component of the peace negotiations, and produced the notorious Article 231 of the Treaty of Versailles. During negotiations preceding the Armistice Agreement as well as in the so-called pre-Armistice Agreement of November 1919, Germany agreed to pay reparations. In the Versailles negotiations, the United States believed that a specific reparations amount should be negotiated; indeed, this was one of Wilson's Fourteen Points. Article 232 of the Treaty expressed the original German agreement with that position: "Germany undertakes that she will make compensation for all damage done to the civilian population of the Allied and Associated Powers." 19 As Colonel House, Wilson's advisor, put it, "[b]y

14. I owe this approach to its use in the somewhat different case of compensation for environmental damage by David Caron, The Place of the Environment in International Tribunals, in THE ENVIRONMENTAL CONSEQUENCES OF WAR 250 (Austin \& Bruch eds., 2000).

15. The most vivid current example is the effort of various classes of U.S. victims of terrorist and rogue-state torts to recover against them under new U.S. legislation. I review this development in the comparative context of German reparations in Richard Buxbaum, Equalization of Burdens, in II FESTSCHRIFT FÜ ERIK JAYME 1051 (Heinz-Peter Mansel et al. eds., 2004); see also W. Michael Reisman \& Monica Hakimi, Hugo Black Lecture: Illusion and Reality in the Compensation of Victims of International Terrorism, 54 ALA. L. REV. 561 (2003).

16. The lack of a state to represent the large class of former German and former Eastern European victims of persecution is a more specific aspect of this reality. See Agreement on Reparation From Germany on the Establishment of an Inter-Allied Reparation Agency and on the Restitution of Monetary Gold, Jan. 14, 1946, art. 8, 61 Stat. 3457, 3171, 555 U.N.T.S. 69, 87 [hereinafter "Paris Reparations Agreement"].

17. These differences also raised the stakes for other issues, such as the cession of the Saar, the occupation of the Rhineland, and, in other treaties, for issues such as the cession of major territories and formation and restructuring of entire nation-states

18. For a review of this development, see BRUCE KENT, THE SPOILS OF WAR 17 (1989); JöRG FISCH, REPARATIONEN NACH DEM ZWEITEN WELTKRIEG 20 (1992).

19. Treaty of Versailles, Jan. 10, 1920, art. 232, 1919 L.N.T.S. 153-54. 
this clause the Allies would have been entitled to all that Germany could pay."20 To lay the groundwork for larger reparations beyond the issue of damages to the civilian population, the French government, in the next round of negotiations, led the European Allies in successfully arguing for a "war guilt" concession. The result was Article 231:

The Allied and Associated Governments affirm and Germany accepts the responsibility of Germany and her allies for causing all the loss and damage to which the Allied and Associated Governments and their nationals have been subjected as a consequence of the war imposed upon them by the aggression of Germany and her allies. ${ }^{21}$

The larger consequence of this post-Armistice coerced confession was to provide the fodder for much of Germany's domestic politics between the two World Wars. But this provision also influenced the discussion of the amount, as well as of the nature of, the later negotiated reparations obligations. ${ }^{22}$ The Allies argued that this moral responsibility had no relation to the size and character of the reparations; but as the leading commentator of the day noted when comparing the general nature of Article 232 with the more detailed and extensive list of reparations categories in Annex I to the Treaty, "in practice, the terms of the Annex will in this case be held to override the main Treaty text. Differences of principle which had to be reconciled are here seen imperfectly fused together in the terms of Peace." 23 Ultimately, the determination of the aggregate amount of reparations and the means of payment was left to a Reparations Commission, and payments beyond a first large tranche were left to the German Government. 24

This brief summary of the situation that arose during and after World War I is relevant for two reasons. Though challenged as an inappropriate use of war guilt to justify larger and broader categories of reparations, ${ }^{25}$ the Treaty of Versailles set a floor for the amount of reparations to be paid after World War II by a Germany whose Third Reich had committed atrocities and wreaked destruction beyond any measure of comparison with the earlier war. At the same time, however, U.S. support of a Weimar Germany enfeebled by early postwar blows, including the reparation burden, led it to resist excessive reparations through a commitment to support a Germany already drained of its productive capacity by those reparations. ${ }^{26}$ In addition, a third issue not yet discussed also arose out of

20. Edward M. House, The InTimate Papers of Colonel House 408-09 (Charles Seymour ed., 1928).

21. Treaty of Versailles, supra note 19, art. 231.

22. Reparations also included the permanent confiscation of private enemy-alien properties in the Allied countries, a matter that also became contentious after World War II.

23. 2 A History OF THE PEACE CONFERENCE OF PARIS 77 (H.W.V. Temperley ed., 1920).

24. Id. at 90 .

25. And not only in Germany. See the Introduction, by Harry Elmer Barnes, to a famous German argument about the effects of Versailles, in ALFRED VON WEGENER, A REFUTATION OF THE VERSAILLES WAR GUILT THESIS xvii-xxvi (Edwin H. Zeydel trans., 1930).

26. It is tempting but anachronistic to suggest further explanation for the possible mitigation of Western reparation claims: the unprecedented destruction of the German landscape, especially the indiscriminate carpet bombing late in the war when its military justification became debatable; the 
the pre-World War II period. In 1924 and again in 1930, Weimar Germany's reparations obligations under the Dawes and Young plans were privatized through bond issues emitted and sold on international capital markets. In the hands of the private sector, these bonds became a significant element during the reparations settlement negotiations after World War II.

II.

\section{WaRTIME AND EARLy POSTWAR REPARATIONS POLICIES AND CONFLICTS}

\section{A. Reparations versus Restitution at the Interstate Level}

\section{The Major Political Context of Reparations}

The question of whether a state's waiver of claims against the offending state also waives those of its subjects was a source of difficulties from the start of negotiations. These difficulties originated, however, in an interstate rather than a state-individual conflict. This section traces the roots of those difficulties to the inter-Allied disputes concerning the concept and scope of reparations sought from defeated Germany. Those disputes both presaged and influenced the Western-Soviet divisions that arose almost immediately upon the conclusion of hostilities; ${ }^{27}$ and they also reflected significant differences between the American and French (and to a lesser extent, the British) positions. ${ }^{28}$ Indeed, it

significant losses of territory after the war; the expulsion of ethnic Germans from the East; and other injuries suffered by the civilian population. Today, these are discussed and politically instrumentalized more freely. However, at the time, these issues figured as arguments of the kind that would, for example, support the Marshall Plan. Eugen Kogon, no apologist, wrote in 1948 that preventing German reconstruction was to condemn Europe to destitution. Eugen Kogon, Man Braucht Deutschland, auch Deutsche Soldaten?, 4 FRANKFURTER HEFTE 18 (1949), reprinted in DIE RESTAURATIVE REPUBLIK: ZUR GESCHICHTE DER BUNDESREPUBLIK DEUTSCHLAND 148 (Michael Kogon \& Gottfried Erb eds., 1996). Even German writers of the 1945-1950 period did not, or could not, put them forward in any but a quantitative sense. They did so primarily in the context of using Western concepts of the protection of property to challenge reparation-based vesting of private German property. See Paris Reparations Agreement, supra note 16.

27. The division leading to the Cold War is neither directly relevant to this narrower question of the reparations sought from Germany, nor within my competence to analyze. Frequently cited sources on this topic include: MARSHALL SHULMAN, STALIN'S FOREIGN POLICY REAPPRAISED (1963) and ADAM B. ULAM, THE RIVALS: AMERICA AND RUSSIA SINCE WORLD WAR II (1971) on the one hand; and Bruce KUKLICK, AMERICAN POLICY AND THE Division OF GERMANY: The CLASH WITH RUSSIA OVER REPARATIONS (1972) on the other; see also JOHN GIMBEL, THE AMERICAN OCCUPATION OF GERMANY (1968). It is common ground among historians that the United States' reaction to the Soviet Union's de facto incorporation of Poland into its realm, despite the expectations created by the Yalta Agreement, was central in the creation of distrust before the war's end. This distrust was later confirmed by United States-Soviet reparations disputes over Germany. See MARC Trachtenberg, A Constructed PeACE 7 (1999). See generally Melvyn P. Leffler, A PREPONDERANCE OF POWER: NATIONAL SECURITY, THE TRUMAN ADMINISTRATION, AND THE COLD WAR (1992) (describing the mutual perception of intentions and capabilities)

28. The best recent sources for this element of postwar history are the detailed studies, based on a comprehensive review of primary source material, of GUNTHER MAI, DER ALLIIERTE KONTROLLRAT IN DEUTSCHLAND 1945-1948 (1995) (placing the reparations issues in the context of efforts to maintain a functioning Allied Control Council); and OTTO NÜBEL, DIE AMERIKANISCHE REPARATIONSPOLITIK GEGENÜBER DEUTSCHLAND 1941-1945 (1980) (providing a detailed account of both the Moscow negotiations preceding Potsdam and of the Potsdam negotiations themselves, 
is the latter set of disagreements that is more immediately relevant to the issue of the waiver of a state's claims, since those disagreements more directly foreshadowed the later conflicts involving the application of the state's waiver of claims to those of its subjects.

The distinction between a state's general claim to reparations and a subject's specific claim to compensation for harm wrongfully inflicted to either personal or property interests became important after the war, though it previously had not been a point of argument at the (Allied) state level. The wartime focus of the Allies was, understandably, on each state's own monetary claims, since it was compensation for the cost of war and of postwar reconstruction that loomed large at that time. Even then, direct monetary compensation of the Allies was considered less feasible and, given the disappointing post-World War I experience with that approach, less desirable than compensation through the seizure of productive capital and monetary assets, the labor of prisoners of war (POWs), and possible diversion of goods production.

A short presentation of what is unavoidably a potted history is essential to demonstrate how East-West conflicts around these issues later led to the legal, even doctrinal, conflicts that are the focus of this article. This summary will also clarify how the preoccupation with traditional war cost claims led to the subordination of concerns for the direct compensation of the victims of persecution, though eventually their unprecedented level of suffering forced the question of direct compensation back to the table.

The Soviet view of postwar Germany's fate was understandably harsh: they wanted the lowest living standard compatible with survival, or at least not higher than the standard of the Soviet Union itself, forcing delivery of goods out of those postwar production facilities Germany would be permitted to retain; the dismantling of all industrial capacity even indirectly related to any potential for rearmament; and if not the lion's then the largest share of compensation claimed by any Allied Power, commensurate with the Soviet Union's largest share of damage. ${ }^{29}$ Through the above means, as well as through incorporation of border territories, the Soviet Union hoped to exercise a continuing influence on Germany; it may also have seen a hopeless German population as a source of revolution, and thus, of direct political influence. ${ }^{30}$

which highlights the role of the reparations debate in setting the course leading to the later creation of East and West Germany). The role of the reparations issue at the later stages of this first period, and specifically in the failure of the Four-Power Council of Foreign Ministers' Moscow Conference of spring 1947-a watershed in sealing the Western-Soviet division-is thoroughly aired in CAROLYN WoOdS EISENBERG, DRAWING THE LINE 358-62, 453-59 (1996); HANNS JÜRGEN KÜSTERS, DER INTEGRATIONSFRIEDE 336-47 (2000). For a somewhat earlier study that still bears reading, see generally ALEC CAIRNCROSS, THE PRICE OF WAR (1986) (emphasizing the role of reparations in the development of the United Kingdom's German policy, but with judicious reflections on the relationship of reparations to the larger issue of Western-Soviet relations).

29. NÜBEL, supra note 28 , at 181 .

30. MAI, supra note 28, at 305-06 (citing Eugen Varga, the influential promoter of the described Soviet policies, as stating that "payment of these compensations doubtless will make the substantive situation in the conquered lands even worse, and in any event lead to a growing dissatis- 
The American view of postwar Germany's fate first formed in reaction to that of the Soviet Union in the preparation of the Yalta Conference, and though it was marked by much internal dissension, ${ }^{31}$ it always had two guiding principles that were of particular importance to the issue of reparations. First, the United States would not underwrite excessive claims against Germany only then to have to support the country; second, it would insist that any postwar policy bearing on Germany, including a reparations policy, be compatible with the larger goal of creating a postwar global economy free of the disastrous beggar-thyneighbor policies that contributed significantly to World War II. ${ }^{32}$

The conflicting principles guiding the Soviet Union and United States necessarily brought in their train a set of secondary policies concerning both the scope and the forms of reparations. The conflict over the implementation of these secondary policies punctuated the next two years and indeed the entire period of active postwar reparations efforts until 1949. While not the thesis of this narrative, a wide consensus among principal actors at the time and of later historians is that the division over reparations was a significant (though not decisive) factor leading to the Cold War. Then-Secretary of State James Byrnes bluntly stated in his memoirs that disagreement about reparations was central to the beginning of the great division between the United States and the Soviet Union; ${ }^{33}$ his successor, George Marshall, called reparations "the heart of the problem,"34 a judgment that analysts of various schools have since supported. 35

Here, it is sufficient to note that neither at the May-July 1945 prepatory Moscow meetings nor at the July-August Potsdam Summit were the Allies able to achieve consensus on the extent and the form of German reparations. By necessity, and given the realities on the ground, the question of a definitive resolution was postponed (eventually ad calendas graecas) and an interim "program" of reparations was agreed upon. This program consisted of little more than acceptance of the actions Soviet authorities were conducting in their Zone and the

faction of their people and to a revolutionary situation").

31. See, e.g., MichaEl Beschloss, The Conquerors: Roosevelt, Truman and the DESTRUCTION OF HITLER'S GERMANY, i 941 -1945 (2002).

32. U.S. STATE DEPARTMENT, II FOREIGN RELATIONS OF THE UNITED STATES: DiPLOMATIC PAPERS 620-21 (1945) [hereinafter "FRUS-II"]

33. JAMES F. BYRNES, SPEAKING FRANKLY 194 (1947)

34. Manuel Gottlieb, The Reparations Problem Again, 16 CAN. J. ECON. \& POLIT. SCI. 22, 25 n.9 (1950); see also Manuel Gottlieb, The German Peace Settlement and the BerLin CRISIS (1960). Gottlieb, an economic adviser of General Clay during the Berlin crisis, offers a lucid review of the large lines of this period in the reparations context (as distinguished from the larger political context), and provides a useful set of comments to support this point. For a valuable example see Edward S. Mason, Economic Relationships Among European Countries, 21 PROC. ACAD. POLI. SCI. No. 4 (Jan. 1946) at 2-15 (1946).

35. This was a principal argument of the early postwar Social Democratic Party. See Adolf Arndt, Status and Development of Constitutional Law in Germany, 260 ANNALS AM. ACAD. POL. \& SOC. SCI. 1, 4-5 (1948) (Arndt puts it simply: the originally planned government of "Germany as a whole" by the Allied Control "has not been realized, for economic unity is impossible without political unity. Economic unity was destroyed from the very beginning by the decision to take reparations by zones."). 
policies that the three Western Occupying Powers then implemented in theirs. ${ }^{36}$ Yet hope for a future agreement remained, and this hope was the principal thread keeping the Allied Control Council, the only four-power German authority, minimally functional for another couple of years, as briefly discussed below. Nonetheless, one major consequence of the non-solution that ratified activities under the "interim" label bears directly on the focus of this article: reparations questions were not settled by the Potsdam Reparations Protocol. ${ }^{37}$ Thus, none of the legal issues bedeviling reparations-especially finality and exclusivitywere settled. ${ }^{38}$

\section{The Allied Conflicts over Restitution in Preference to Reparations}

The immediate practical consequence of this impasse was a return by the three Western Occupying Powers to the older but largely neglected question of sharing future reparations among the Western Allies and other nations that had entered the war against the Axis Powers. Within this group, the already described issues of the Western-Soviet conflict were not of major concern; rather, it was each nation's own division of the pie that was of foremost interest. The composition of reparations, whether in monetary assets, productive facilities and other physical assets, deliveries out of current production, or even temporary use of prisoners of war as a labor force, now came to the fore. With this change of priorities another element of the Allies' earlier wartime planning again became relevant, namely the treatment of the German wartime seizures of facilities, and of state and privately owned monetary and non-monetary assets during the period of German occupation. This recreated the distinction between a generic equal-treatment reparations policy and one granting priority over specific properties.

This focus on the distinction between generic and specific reparations necessarily brought with it questions of tracing, and thus of restitution as a complement or possible alternative to reparations. The restitution of property, the ownership of which was traceable to original owners or their appropriate successors, is not, however, a simple matter. Restitution of property is not conceptually limited to state-owned property, and already during the war the Western Allies discussed whether to distinguish between the restitution of property taken by the Third Reich from its own subjects and property taken from the subjects of occupied or other enemy countries. That situation has its own history and is the subject of a separate discussion found below. ${ }^{39}$ A policy governing the right of a state to claim a restitution-type priority to state or privately owned assets traceable to its territory, however, could not be postponed because it could not be separated from the question of traditional reparations paid by the Axis States to

36. See, e.g., NÜBEL, supra note 28 , at 171 ; MAI, supra note 28 , at $310-11$.

37. For its text, see FRUS-II, supra note 32, at 1485-87.

38. See NÜBEL, supra note 28 , at 202.

39. See Paris Reparations Agreement, supra note 16. 
the Allies in the event of an Allied victory.

The restitution-reparations connection began with the introduction of the subject of restitution by British and French members of the European Advisory Commission late in 1944, an action in turn derived from the Reparations Protocol, a major element of the Yalta Agreement. ${ }^{40}$ In his January 1945 instructions to Ambassador Winant, Secretary of State Stettinius made clear this connection:

[T] he question of replacement, in so far as that term is more broadly construed than merely the replacement of looted and unrecoverable or destroyed works of art and similar unique objects, is closely related to the general problem of reparation on which discussion is still going forward here. You should, therefore, withhold comment on any replacement proposals other than those limited to the class of unique cultural objects.... [Further, it] should be definitely provided that the Restitution Commission will be a sub-commission of whatever Reparation Commission is eventually set up. 41

One reason for this separation was an effort to keep any productive facility whole, though its components might have come from separate and identifiable sources. The Allied powers wanted to keep production facilities whole to prevent stripping essential components of such facilities. ${ }^{42}$ This related to the focused determination of the United States, so far as it was in its power, to cast the reparations issue as a bankruptcy problem, making the equal treatment of all claimants the touchstone policy. ${ }^{43}$ In this effort, the predictable noncooperation of the Soviet Union was less problematic than the efforts of the French government to use traceable ownership of looted productive assets as the basis for a superior claim to those assets. ${ }^{44}$ The U.S. policy was closely tied to

40. FRUS-II, supra note 32 , at 1048-51.

41. U.S. STATE DEPARTMENT, III FOREIGN RELATIONS OF THE UNITED STATES: DIPLOMATIC PAPERS 1172 (1945) [hereinafter "FRUS-III"]; see also id. at 1198 :

[W] hile the Department's policy has been to advocate restitution of all identifiable looted property... I understand that the Department still deems it desirable that the restitution of productive equipment should be treated as a separate category and should be limited by reparations principles. While productive equipment like other looted property may be considered, .... it should be borne in mind that the problems of possible conflict with or subordination to reparations principles are particularly acute where such equipment is concerned. For this reason... the principle of the restitution of large amounts of productive equipment should be avoided as far as possible.

42. Id. at 1187 ("A reparation decision to transfer a plant to one claimant should not ... be frustrated by the absolute right of another claimant to remove a vital and irreplaceable machine, which is a minor part of such plant ... I cannot see how such difficulties can be avoided if the restitution of productive equipment is handled by a body independent of the Reparations Commission.").

43. An interesting later echo of exactly this concept as a justification for the prioritization of claims by persecutees of the Nazi regime is found in Philipp Auerbach, Restitution for Victims of Nazi Persecution, 260 ANNALS AM. ACAD. POL. SCI. 131, 133 (1948) ("We must start with the theory that postwar Germany is like a bankrupt estate, in which the claims of those persecuted for racial, religious, and political reasons are like the claims of preferred creditors in a fraudulent bankruptcy case.").

44. While not given sufficient honor at the time, this was a perfectly understandable position. Of the three major powers, only France was occupied and suffered industrial demontage by German forces and industries. See, e.g., Superior Military Government Court of the French Occupation Zone In Germany, Judgment of 25 January 1949 In The Case Versus Hermann Roechling And Others Charged With Crimes Against Peace, War Crimes, And Crimes Against Humanity. Decision 
its post-World War I experience. The United States wanted to keep a defeated Germany capable of some level of self-sufficiency, lest the country's inability to meet its population's minimum needs would again lead to an American obligation to return, through aid, what the reparations policy had given the Allies.

With the surrender of Germany and the convening of the Potsdam Conference in May of 1945, formation of both the policies and institutions concerned with reparations and restitution became more urgent. These priorities are apparent from the formal Presidential instructions issued to the U.S. Representative on the Allied Commission on Reparations:

In determining the size and character of reparation in accordance with [the Yalta Agreement] Reparation Protocol and the allocation thereof among the various claimant nations the following principles are advocated by this Government: . . .

(d) This Government opposes any reparation plan based upon the assumption that the United States or any other country will finance directly or indirectly any reconstruction in Germany or reparation by Germany .... (j) It will be inevitable that the German standard of living will be adversely affected by the carrying out of the Reparation Plan. However,... (k) [t]he Reparation Plan should not put the United States in the position where it will have to assume responsibility for sustained relief to the German people. 45

The other principal of this policy-the bankruptcy analogy-became equally clear at the time. After the failure of the mid-1945 pre-Potsdam Moscow Conference on Reparations, the U.S. Representative on the Allied Commission on Reparations instructed the U.S. Military Governor for Germany (General Eisenhower) on the U.S. goals for restitution activities in the U.S. Zone:

[A]ny removal of ... [restituted] property should be made only if the government of the receiving country agrees, by executing a formal receipt stating that the property in question may ultimately be deemed 'restitution,' 'reparation,' or an 'export' for which payment shall be made [to the contingent status of that removal]. ... 46

This was not only a rebuff to the Soviet Union, which was proceeding with $d e$ montage reparations in the Soviet Zone and would continue with reparations from current German production for some time. In addition, this principle was aimed at the French government, which had all but given up on expecting future reparations and saw its interests better served by upgrading to a separate concept of restitution as its preferred definition of reparations instead of equal treat-

\footnotetext{
On Writ Of Appeal, in Trials Of War Criminals Before The Nuernberg Military Tribunals 14 T.W.C. 1097 (1950). France therefore could, with some justification, argue that a broadly defined definition of what property could be used as restitution was appropriate. On the other hand, given the devastation the Soviet Union had suffered, it is understandable that even the U.S. authorities on the ground were very critical of the French "intransigence" that threatened to reduce legitimate flows of industrial equipment to the Soviets. For example, see the strong comments made by General Clay reported in WOLfGang KRIEgER, GeNeral LuCIUS D. Clay UND DIE AMERIKANISCHE DEUTSCHLANDPOLITIK, 1945-1949 at 145-47 (1987).

45. Instructions for the United States Representative on the Allied Commission on Reparations (Pauley) (May 18, 1945), in FRUS-III, supra note 41, at 1222-24 (footnote omitted).

46. FRUS-III, supra note 41 , at 1260.
} 
ment. ${ }^{47}$ This battle continued throughout 1945 and 1946, but for our purposes it suffices to confirm that throughout this period the U.S. Military under General Clay maintained its position. He held that exorbitantly defined restitution claims by formerly occupied Allied Powers could not compromise or prejudice the priority of reparations, especially in the context of diminishing the German economy's capacity to generate a level of production sufficient to keep further U.S. subsidization of the population to a minimum. ${ }^{48}$

While the "bankruptcy-administration" reason for categorizing restitution as a subset of reparations diminished over time, ${ }^{49}$ it survived long enough to become a bridging argument for the subordination of restitution (as well as of personal compensation for other delicts affecting life, liberty, health, or property) within the framework of the later London Debt Agreement. ${ }^{50}$ First, however, it played a large role in the eventually frustrated effort to provide a fair share of reparations to those Allied countries that did not have the benefit of self-help enjoyed by the Occupying Powers. ${ }^{51}$

47. See MAI, supra note 28 , at 349 ("France insisted on the separate treatment of restitutions and reparations; first, to win a veto power against the reparations decisions of Potsdam; second, because it expected a more expeditious fulfillment of its demands in this arena [of restitution]." ). This position should be viewed within the context of France's exclusion from the Potsdam Conference and its efforts to "renegotiate" those aspects of the Conference's decisions that had particular relevance to its policy wishes. See, e.g., KüSTERS, supra note 28 , at 269.

48. In addition, the United States reluctantly accepted the addition of goods to the concept of reparations:

To the extent that for political reasons it may become necessary in the negotiations to agree that reparations be collected in the form of deliveries of goods from current production over a period of years, such goods should be of such a nature and in such amounts as not to require ... the continued dependence of other countries on Germany after reparations cease.

FRUS-III, supra note 41 , at 1223 . Given the exiguous situation in the formerly occupied countries, this became an important component of reparations in the first years, and thus, unavoidably, an element of U.S. policy even in its own zone.

49. The argument in favor of restitution did play an important role during the negotiations of the Paris Agreement of 1946 and on the form and division of reparations. See, e.g., The Netherlands Government, Memorandum of the Netherlands Govemment Containing the Claims of the Netherlands to Reparations from Germany 5 (1945) (citing U.S. bankruptcy law to support the claim that "the people of the Netherlands have the undoubted right to the earliest possible restitution of identifiable looted property taken from the country by the Germans, when such property is found outside the Netherlands, either in Germany or elsewhere," and defining this to include "all goods by their nature fit for restitution... [ [whether removed] either directly by acts of transfer or of dispossession, or indirectly by purchases or by transactions effected by means of payment which were created, imposed or extorted by the enemy due to the occupation.").

50. Another aspect of this early controversy bears on another issue of recent importance: that of the exclusivity of interstate handling of individual damage (at least in terms of property). It was understood at the time that even the restitution of private property was to be dealt with, on behalf of the owners, by the state of which the owner was a subject.

51. This self-help was legitimated by the United States in the instructions, though they excepted that all property removals would eventually be accounted for:

As an interim program,... [d]uring the initial period following the collapse of Germany each of the four occupying powers-Great Britain, Russia, France and the United Statesmay remove from its zone of occupation in Germany plants, equipment and materials (including current output) of such a nature and not in excess of such amounts as may be determined by the Reparation Commission .... Records should be kept of all deliveries... and such deliveries should be made without prejudice to the final allocation of reparation 
Defining (prioritized) restitution as narrowly as possible should not, however, obscure a larger point: the U.S. policy on the issue of reparations, including the restitution side issue, was based on an early realization that its own interests would not be served by a radical demontage, and an equally radical forced export of such German products as the Western Zones' diminished industrial plants could produce. Between the heavy burden of supporting displaced persons and supplying sufficient food imports for its share of the German population, the need for German production as a major factor in European reconstruction was clear. It was this recognition of conflicting needs that led the United States to play a moderating role against the larger demands of the British and especially of the French governments. ${ }^{52}$ This moderation became clear at least as of late 1946, and was confirmed by the failure of the 1947 Moscow Conference, ${ }^{53}$ which in turn confirmed the Cold War as an enduring reality. Thus, any future reparations would be relevant only to the Western occupying powers and to the other formerly occupied Western allies.

\section{B. The Development of State Expectations of Reparations and Compensation}

In order to put this stage into perspective, a brief review of the wartime planning for the postwar situation of the European Allies is necessary. The occupied Allies, as well as the smaller nations that were combatants-at-arms with Soviet, U.K., and U.S. forces, participated in this planning through their governments-in-exile. The broadly defined costs of war and occupation these nations suffered, and the role of reparations in making them whole, were major concerns for these governments and nations. The outcome at Yalta, which seemed to address their concerns, also encouraged engagement with these issues.

\section{Early Legislation and the Occupied Countries}

As a result of the focus of the Yalta Conference on issues of reparations and compensation, a number of these countries, especially those occupied by Axis forces during the war, enacted legislation both at the time of their occupation and immediately after the war, providing a domestic-law basis for the restitution of, or compensation for, loss of property. This legislation also included some compensation, often under wider social-insurance schemes, for loss of life or liberty and damage to health and other personal elements. In 1951, Nehemiah Robinson classified the policies as follows:

(a) those in which a registration of such losses has been made but no action taken

shares.

Instructions for the United States Representative on the Allied Commission on Reparations (Pauley), supra note 45 , at $1225-26$.

52. While a number of excellent secondary works support these conclusory assertions, I rely largely on MAI, supra note 28.

53. See KÜSTERS, supra note 28 , at $375-76$. 
to assess, let alone compensate, the damage; (b) those where the principle of war damage compensation is recognized but no legislation has yet been enacted to provide for actual compensation payments; (c) those which carry on their statute books partial measures of compensation; (d) those which, in addition to insurance schemes, have certain regulations for common war damage compensation; and (e) those ${ }_{4}$ which have enacted and implemented comprehensive legislation to this effect. $^{54}$

Much of this legislation was enacted in anticipation of reparations that would flow from the defeated Axis countries to the Allied powers whose territories had been occupied, or which had been at war on the side of the Allies. Some of this legislation was a natural extension of coverage that the Scandinavian countries had established under comprehensive social welfare legislation to victims of war and occupation, but these policies did not contradict the expectation of reimbursement through reparations as well. That expectation, to the extent it rested on the immediate postwar recoupment process established by the Allied Paris Agreement of 1946 and contemporaneous bilateral arrangements for the return of property located in neutral countries such as Switzerland, was at first disappointed, as the following account will clarify. Eventually, some payments were made, primarily by Germany, as a result of the Federal Republic's later ability to bear these outlays. So far as distribution to the intended beneficiaries is concerned, that too is necessarily included in any account that explores the interplay of domestic and international legal and political issues.

\section{The Early Postwar Reparations Program of the Western Allies}

For the purposes of this legal-historical narrative, then, the road now leads to the effort of the Western Allies, led by the three Occupying Powers, to find agreement on the amount, relative shares, and procedures to extract reparations from Germany and the other European Axis powers. While France and Great Britain were already actively engaged in self-help reparation activities, all three Powers agreed that the others could satisfy their claims only out of those German assets (including financial assets) that could be marshaled in other countries. Except for the restitution of specific identifiable equipment and inventory removed during the German occupation, they would not be entitled to join in the direct claim to in-country industrial facilities, capital goods, or current production that represented the bulk of the Occupying Powers' receipts.

Before a review of this next stage, however, a preliminary comment about the relationship between interstate reparations and the later direct compensation for victims' personal and property injuries is necessary. The constant if constantly challenged argument of the postwar German Federal government is that all issues of compensation and restitution for the benefit of non-German subjects were properly subsumed exclusively under the heading of interstate repara-

54. Nehemiah Robinson, War Damage Compensation and Restitution in Foreign Countries, 16 LAW \& CONTEMP. Probs. 346, 347 (1951); see also, H.R. Doc. No. 83-67, at 29-32 (1953) (providing a brief description of the war claims arising out of World War II). 
tions. ${ }^{55}$ This view is better contextualized by considering the centrality of interstate reparations to the three Western members of the Four Powers, not to mention the Soviet Union, during this early postwar period. ${ }^{56}$ Indeed, while this is not within the purview of this article, it should be noted that reparations were so critical that their priority represented the only intra-Western counterargument against the zonal division of Germany. ${ }^{57}$ It was not until March of 1948 that the intentional abandonment of the Four-Power Allied Control Council signaled a total abandonment of German unity; until then, a united country was considered an essential prerequisite to a successful reparations policy. ${ }^{58}$

Now, however, it is appropriate to return to the division of reparations among the Western Allied Powers, a division made necessary by the failure of the Potsdam Agreement.

\section{The Road to the Paris Reparations Conference}

\section{The Position of the States}

With the separation of the Soviet Union's reparations from those of the three Western Occupying Powers, ${ }^{59}$ the United States turned to deal with the strongly presented reparations claims of the Western Allies, especially those occupied by German forces during the war. In July of 1945, while in Moscow preparing for the Potsdam Conference, George Kennan submitted to the State Department a list of thirteen countries with justified reparations claims against the resources available from the three Western zones. ${ }^{60}$ After first resolving the

55. For a good recent example, see generally ALBRECHT RANDELZHOFER \& OLIVER DÖRR, ENTSCHÄDIGUNG FÜ ZWANGSARBEIT?: ZUM PROBLEM INDIVIDUELLER ENTSCHÄDIGUNGSANSPRÜCHE VON AUSLÄNDISCHEN ZWANGSARBEITERN WÄHREND DES ZWEITEN WELTKRIEGES GEGEN DIE BUNDESREPUBLIK DEUTSCHLAND (1994) (providing a general argument that interstate reparations covered non-German reparations as well). The specific argument on this topic focuses on the interpretation of reparations treaties and related agreements; that is, whether they commit the claimant states to waive further claims for themselves and for their subjects, whether against the paying state or against its subjects. For an articulate argument for this position, see Rudolf Dolzer, The Settlement of War-Related Claims: Does International Law Recognize a Victim 's Private Right of Action? Lessons after 1945, 20 BERKELEY J. INT'L L. 296, 318-21 (2002).

56. It was, obviously, less central to the interests of the United States.

57. See Paris Reparations Agreement, supra note 16.

58. The best recent treatment of this interplay of reparations policy, the role of the Allied Control Council, and their respective impacts on the pre-1948 unification debate, is that of MAI, supra note 28. For an English-language treatment, see EISENBERG, supra note 28. See also KUKLICK, supra note 27. However, the drive to establish U.S. responsibility for the slide into the Cold War has given rise to some challenges; these challenges are only partly rebutted by Eisenberg. An impression of the effort of the American and Soviet Military Governors (Clay and Sokolovsky) to maintain the possibility of a united Germany against the political winds of Cold-War division can be garnered from JoHn H. BaCker, Winds of History-The German Years of LuCIUS DuBignon Clay $169-77$ (1983).

59. Paragraph three of the Protocol on German Reparations signed at Potsdam on August 1, 1945, provided, "The reparations claims of the United States, the United Kingdom and other countries entitled to reparations shall be met from the Western Zones and from appropriate German external assets." FRUS-II, supra note 32, at 1485.

60. FRUS-III, supra note 41 , at 1238. 
United Kingdom's opposition to the inclusion of Denmark because it had not resisted the German takeover, ${ }^{61}$ the Allies agreed that non-military Allies, such as the Latin American countries, could satisfy their costs by using German assets found in their territories. ${ }^{62}$ Accordingly, on August 28, the United States, United Kingdom, and France sent an invitation to Australia, Belgium, Canada, Czechoslovakia, Denmark, Egypt, Greece, India, Luxembourg, the Netherlands, New Zealand, Norway, the Union of South Africa, and Yugoslavia. The invitation called upon these countries "to submit data relating to [your] reparation claim ... against Germany and the value of prewar German assets situated in [your] territory." ${ }^{63}$ In the accompanying "Draft Memorandum" of that Commission, the Western Allies announced a conference to agree upon and finalize the allocation of reparations from the Western Zones of Germany among the countries entitled thereto. This became the Paris Conference, which was held during the last three months of 1945 and led to the Paris Agreement of January $1946^{64}$

The "suggestions" (which were, in fact, instructions) given each invited country concerning the claims it could present at the reparations conference are noteworthy as they forged both state and individual expectations for compensation. Five major categories of claims were created: damage to and loss of property (excluding military property); budgetary expenditures ascribed to the prosecution of the war; the broadly defined "man-years" expended or lost in connection with the war-including "loss of life or health and injuries sustained by civil and military victims of the war and occupation;" $" 65$ the cost of German occupation including forced payments and credit extensions; and, finally, "all other [war-connected] claims of a governmental or private nature."66 Separate instructions called for data concerning prewar holdings of German governmental and private-sector assets in the claiming country, since their marshalling and distribution were expected to become a significant proportion of the reparations process. ${ }^{67}$

At this early stage, at least, the presentation of personal and property claims of individual and legal subjects of the claiming state was seen as a function of the state; direct presentation of claims by those subjects was not then contemplated. Nevertheless, the fact that subjects might, at least indirectly through state reparations, receive compensation for loss from their state marked a departure from the reparations practices of earlier times. ${ }^{68}$

61. Id. at $1266,1299$.

62. Id. at 1266; see also, Paris Reparation Agreement, stupra note 16, at 3157.

63. The Secretary of State to the Australian Minister (Eggleston) (Aug. 28, 1945), in FRUSIII, supra note 41 , at 1268 .

64. Id. at 1357; Paris Reparation Agreement, supra note 16, at 3157.

65. Memorandum of Allied Commission on Reparations, Annex A of FRUS-III, supra note 41 , at $1268-70$

66. Id.

67. Id., at Annex B, 1270-72.

68. Unlike the Mixed Commission between the United States and Germany that was established after World War I to receive and adjudicate private property claims for war-related losses (see 
Also important was the immediate subordination of the other Western Allies' claims to the interests and policies of the three major players, especially the United States. ${ }^{69}$ Indeed, from the outset, the United States made no pretense of equal treatment for other claimants. Secretary of State Byrnes went so far as to characterize their expectations as illusory. ${ }^{70}$ A major reason for this subordination, however, was the ongoing debate with the Soviet Union over the Occupying Powers' self-help policies. These included the Soviet demands, accepted in principle by the Big Three (United States, United Kingdom, and France), for a continuing share in the Western Zones' productive output given the Soviet Union's higher wartime losses. From the Occupation perspective, the reparation discussions in Paris were a subset of the new policies necessary to dismantle German war capacity, as tempered by the survival needs of the population. Therefore, the procedures established in Paris had to be coordinated with, and even subsumed within, the reparation component of those policies. ${ }^{71}$

This subordination was expressed most clearly in the structure of the InterAllied Reparations Agency (IARA). The United States, United Kingdom, and France would nominate three of the five members of the Agency, and the other two seats would rotate among the other countries. However, the power to appoint Agency executives was vested in only the three permanent seats of the United States, United Kingdom, and France. The IARA would resolve disputes, especially over the allocation of reparation shares that the Paris Conference could not resolve. In essence, this guaranteed the Big Three a veto power at Paris and, consequently, an affirmative allocation power via the IARA. While the motive for control of the allocation process was, in part, the relationship with the Soviet Union, the overriding concern was with the appropriate control policies toward Germany and their implementation. ${ }^{72}$ The process of implementation over the next decade bears centrally on the theme of this study.

\footnotetext{
Mixed Claims Commission, United States and Germany, First Report (Bonynge) (1925)), those commissions established after World War II were creations of the Paris Reparations Agreement intended to deal with the conflicting restitution and reparations claims of the Western Allies as states, and only indirectly involved private claims. Agreement on Settlement of Indebtedness of Germany for Awards Made by the Mixed Claims Commission, Feb. 27, 1953, U.S.-F.R.G., 4 U.S.T. 1953. For a brief review, see Ernst Féaux de la Croix, Interalliierte Reparationsagentur, in 2 WÖRTERBUCH DES VÖLKERRECHTS 29-31 (Hans-Jürgen Schlochauer ed., 1961). A detailed legalhistorical study of the Mixed Commission appeared only recently. See BURKHARD JÄHNICKE, WASHINGTON UND BERLIN ZWISCHEN DEN KRIEGEN (2003). However, contemporaneous reviews were published variously in the 1920s. See e.g., Edwin Borchard, The Opinions of the Mixed Claims Commission, United States and Germany, 19 AM. J. INT'L L. 133 (1925).

69. The United Kingdom was apparently more concerned about the procedural if not the substantive rights of the smaller Allies. See FRUS-III, supra note 41, at 1313.

70. See id. FRUS-III, supra note 41 , at 1389.

71. The Four-Power Allied Control Council continued to endeavor to establish those policies both during, and even after the failure of, the Potsdam Meeting (and the later Four-Power Foreign Ministers' London Meeting) to harmonize Soviet and Western positions on these matters.

72. This is the recurrent theme of the many exchanges between French, British, and American cabinet-level officials during the preliminary discussions that preceded the diplomatic conference that eventually led to the conclusion of the Paris Reparations Agreement. Paris Reparation Agreement, supra note 16. See generally FRUS-III, supra note 41, at 1169-1506.
} 
The first outcome of 1945 was agreement on the style of the negotiations themselves and the forms of reparations. Reparations were framed as an interstate matter and individual losses and expectations of compensation were moved offstage, except to the degree domestic politics influenced state positions. ${ }^{73}$ The second outcome was setting the stage for the eventual disappointment, over the next decade, of the smaller Allies' reparations expectations. ${ }^{74}$

The first ground for these outcomes lies in the decision of the Big Three, reflected in the Paris Treaty, to relegate the smaller Allies largely to German external assets marshaled in their own countries and in the neutral countries, such as Switzerland. ${ }^{75}$ The second lies in the initial insistence of the Big Three on the exclusivity of the reparations arrangement reached at Paris. Angell, leader of the U.S. delegation, explained in the minutes of the Drafting Committee:

[A]ll claims, of whatever nature, by a government for reparation from Germany are, in effect, consolidated into a single claim which has been considered at this Conference, and furthermore that the German reparation which is made available to each government in accordance with its agreed quota shall be the sole source of satisfaction of its consolidated reparation claim against Germany. ${ }^{76}$

A number of delegations, including the French, objected to this understanding of the relevant passage of the Agreement. They insisted that they had the right either to participate in the Allied Control Commission's later determination of the amount and duration of German reparation transfers, or at least participate in political negotiation of a "final reparation settlement.",77 The latter, which Angell felt was implied in the phrasing of the official text, became the leitmotif of the next decades. In particular, it resurfaced during the prolonged debate over the terms of the critical elements of the London Debt Settlement Agreement of $1953,{ }^{78}$ especially of the moratorium imposed on any further efforts to hold the Federal Republic or its private sector responsible for payment of any reparations

73. Except for the United Kingdom's concern with the protection of its export markets from future German competition, domestic actors' concerns (in the modern parlance) were sublimated into more general national policies, especially the U.S. policy of fostering a postwar climate of a liberal international economic regime.

74. While it would not advance this narrative to provide the details of the bargaining structure or the arguments over percentage shares of the overall allocation (which was not finally determined by the Conference but by the coordinated work of the IARA and the Allied Commission on Reparations of the Allied Control Council), suffice it to provide the following example:

Shares as proposed ... [were] presented to Conference .... Serious objections were stated by delegates of Belgium, Albania, Luxembourg and Egypt .... Gutt spoke for Belgium ... and demanded, as a minimum, a one percent increase in B category .... At subsequent meeting ... the adjusted shares were presented after distribution of Canadian renunciation and a renunciation of $0.8 \%$ by South Africa .... The Belgian share was increased only $0.4 \%$.... Gutt still remained obdurate and finally US, UK and France each reduced its share in category B by $0.15 \%$ so that Belgian share could be increased in total by $0.50 \%$ of which $0.10 \%$ was released to Luxembourg .... Additional $0.05 \%$ was released by US, UK and France to make possible increase of Greek share in total by $0.25 \%$.

Report of Angell to Secretary of State, December 24, 1945, FRUS-III, supra note 41, at 1489-90.

75. Paris Reparation Agreement, supra note 16, at 3157.

76. FRUS-III, supra note 41 , at 1479.

77. Id. at 1480

78. See Agreement on German External Debts, Feb. 27, 1953, 4 Stat. 443, 333 U.N.T.S. 3. 
outside the framework of the Agreement itself. ${ }^{79}$

At the Paris Conference, the objecting Allies were less concerned with the future of reparations than the fact that the allotments agreed to in Paris amounted to little more than recommendations to the IARA. The IARA's ability to enforce reparations was extremely limited because it was dominated by the three Western Occupying Powers. Any of the IARA's policy efforts would be subordinate to the Allied Control Commission's future plan of action, which included industrial demontage and restitution. Angell understood these concerns, and considered them justified. ${ }^{80}$ His proposed response was to provide "that the acceptance of the reparation quotas by the various governments represented at the Conference shall be without prejudice to the rights which the signatory governments may have with respect to the final settlement of German reparations." 81 Some of the governments that later objected to the moratorium language of the London Debt Agreement, together with the French government that was still concerned about its concept of restitution, instead proposed a specific right to "present claim[s] against future German Government[s] for [the] unsatisfied balance of its total reparation claim." 82 This would have implied a yetunspecified denominator in each case, one that would by definition involve the later reopening of arguments about relative shares. Even in the immediate context of Control Commission reparation determinations, the United States rejected direct participation of the objectors in that activity. ${ }^{83}$ Angell's decision to exclude these countries had future repercussions on, specifically, their political participation in a final reparations settlement, which he advised the delegates was "implied in the phrasing adopted." 84 With this official gloss on the Paris Agreement, subsequent arguments that its terms included a waiver of future or further claims deprived it of much textual legitimacy. ${ }^{85}$

79. See id., supra note 78 , art. 5 at 14 .

80. He reported to the State that these countries felt that:

inasmuch as it is the Control Council, under the direction of the four occupying powers which in practice determines the forms, duration and total amount of German reparation, they are not prepared to renounce their reparation claims against Germany in advance of the actual receipt of their respective shares in the total amount of reparation to be made by Germany.

Note of December 18, FRUS-III, supra note 41, at 1479.

81. Id. This phrase, "without prejudice... with respect to the final settlement of German reparations," became the disputed term of art throughout the later era.

82. Id. at 1480 .

83. Id. at 1478 .

84. Id. at 1480

85. This was the same result obtained by a different route. Those among the Allied negotiators who read the Potsdam Declaration as including this waiver, and the Paris agreement as implementing it, agreed that the failure to implement the Paris Agreement over the next five years negated the waiver as of that time. For a contemporaneous account of public international law principles as bearing on these waiver issues (in the context of the 1947 peace treaties with former Axis members), see G. G. Fitzmaurice, "The Juridical Clauses of the Peace Treaties," 1948:II Rec.Cours 255 (1948), at $339 \mathrm{ff}$. The implications of this (not quite unanimous) consensus are discussed below. For the resonance and rejection of the waiver argument in U.S. courts, see, for example, the class action lawsuit Iwanowa v. Ford Motor Co., 67 F. Supp. 2d 424, 458 (D.N.J. 


\section{The Position of Individual Survivors and the Displaced Persons Community}

At this earliest postwar stage, compensation for individual suffering, especially of those persecuted under the National Socialist regime, was only indirectly touched upon in the reparations negotiations. Relief for the multitudes of Displaced Persons was a major issue, especially for those who had been subjects of the Third Reich and those who could not or would not return to the devastated regions of their origin in Central and Eastern Europe. These groups were essentially stateless and could not expect to benefit, even indirectly, from the distribution of welfare benefits that the subjects of those Western Allies present in Paris might receive from the reparations paid to their states. The only reference to compensation of individual victims at this time was a comment by Secretary of State Byrnes to the U.S. delegation in Paris in early December when the final text of the Paris Agreement was under negotiation. Byrnes emphasized that the separate allotment for Displaced Persons (discussed immediately below) would not suffice to compensate victims fully. He added, in cablelese:

[O]ccupying powers, United Nations (thru UNRRA and otherwise) and private charities thruout world recognize their obligations. Because reparations will consist largely of payments in kind and will leave Germany with economy capable only of paying for essential imports, Germany cannot be made to compensate in full victims of Nazi persecution who have left or will leave Germany. Proposal therefore is simply to add small amount liquid assets, which can be made available to supplement other arrangements. Restitution of property taken from victims of Nazi persecution will, of course, be made in Germany, but can hardly be expected to benefit refugees substantially. ${ }^{86}$

As a result of these sentiments, an ad hoc solution to the problem of statelessness and lack of representation was cobbled together in the weeks of the Paris negotiations; it was no more than an embarrassing sop to conciliate the demands of the Displaced Person's "community" and its representatives, especially those among Jewish relief organizations. ${ }^{87}$ Nevertheless, the episode is important, both for why and how it occurred, and for what it established in the way of standing for non-governmental organizations to become subjects and actors within an evolving international regime. It therefore deserves to be described in some detail. At the same time, however, it needs to be separated from an impor-

\footnotetext{
1999). The principal case dismissing the class actions brought in the $1990 \mathrm{~s}$, Burger-Fischer v. Degussa, 65 F. Supp. 2d 48 (D.N.J. 1999), deemed these state-exclusivity and waiver issues "revived" by later treaty and statutory actions that rendered the failure of the Paris Agreement moot. The court considered that the transfer of sovereignty to the new Federal Republic, requiring it to enact legislation to compensate victims of persecution, indicated acceptance by the U.S. government of the exclusivity doctrine. Id. at 273 . This result should be seen in the larger context of the "political-question" non liquet abstention that led to the court's dismissal of all claims. For a litigator's critique of these courts' use of the historical record, see Stephen Whinston, Can Lawyers and Judges Be Good Historians?: A Critical Examination of the Siemens Slave-Labor Cases, 20 BERKELEY J. INT'L L. 160 (2002).

86. Cable of December 10, 1945, to Angell, FRUS-III, supra note 41, at 1452.

87. See, e.g., Seymour Rubin \& Abba Schwartz, Refugees and Reparations, 16 LAW \& CONTEMP. PROBS. 377 (1951).
} 
tant parallel argument concerning compensation for the Jewish victims of Nazism and its institutional implementation, even though both lines converged in Paris.

The first official broaching of the concept of using German assets to support the stateless refugees at Paris was a proposal sent to Angell by the State Department for preliminary discussion with France and the United Kingdom. Edwin Pauley was appointed by Truman as a kind of roving ambassador to work (or interfere) with the development and implementation of reparations policies before and after Potsdam. He made a proposal that probably arose from his direct observation of the problem of Displaced Persons in the U.S. Zone of Germany. After some policy disagreements about the implications that support of Displaced Persons would have for their eventual repatriation, 88 an agreement was reached to reserve a percentage of German external assets (principally those located in neutral countries, plus non-monetary gold $)^{89}$ for the support of this community. This was institutionalized in a parallel "Five Power Conference on Non-Repatriable Refugees," which convened in Paris later in 1946 to implement Part I Article 8 of the January Agreement; its members included France, the United Kingdom, the United States, Czechoslovakia, and Yugoslavia. Discussions with representatives of the American Jewish Committee present at the Conference resulted in limiting the concept of "non-repatriables" to those who had been in concentration camps. ${ }^{90}$ This formulation met the concerns of delegates such as the Yugoslavs, who wished to avoid support of those of its subjects among the Displaced Persons who had been on the German or Royalist side. $^{91}$ Also, the absolute sum of $\$ 25,000,000$, earlier proposed by Angell, was accepted more because it was considered a feasible amount to collect than because of its adequacy. ${ }^{92}$

Administration of the funds was left to the Inter-Governmental Committee on Refugees, which also had its plenary meeting in Paris, parallel with the Reparations Conference. ${ }^{93}$ In a final proposal before the Conference moved to the

88. "[The] British are fundamentally opposed to plan on general ground that it may discourage voluntary repatriation and commit British to general aid for non-repatriables with attendant complications for British Palestine policy." Angell to State, FRUS-III, supra note 41, at 1438.

89. This poorly defined term has its own history. See ARTHUR LEE SMITH, JR., HitLer's GOLD: THE STORY OF THE NAZI WAR LOOT 158 (1989), and an earlier review by Elizabeth B. White, The Disposition of SS-looted Gold During and After World War II, 14 AM. J. INT'L. L. 213 (1953).

90. Even this was protested by some formerly occupied country delegations, which feared it would give more to Displaced Persons than to persons injured in their home country during the Nazi occupation. FRUS-III, supra note 41 , at 1451 .

91. Representatives of these countries on the Inter-Governmental Committee on Refugees had veto power over distributions to such classes of persons. Id. at 1459.

92. Id. at 1437.

93. Id.; see also ELI GINZBERG, MY BROTHER's KEEPER 74-75 (1989). Ginzberg, the U.S. Representative at this meeting, adds:

[T] he British were unfriendly, since they had other ideas about the money (looking to use it as a down payment of their dues to the International Relief Organization) and were afraid that if the Jewish Agency and the Joint Distribution Committee were the beneficiaries it would put additional pressure on ... [them] to issue additional immigration visas for refu- 
horse-trading of allocation percentages and eligible assets among the state delegations, Angell added that "claims of individual refugees against [the] future German government were to be preserved." 94 That comment, too, has its own ties to the future.

While this aspect of the reparations arrangement began to support a group of persons who had no state to support them, nor a place to which they could reasonably be expected to return, its limitation to only concentration camp survivors changed the direction of the relief effort. This sum of $\$ 25,000,000$, a sum considered "pitifully small" by the United States even then, ${ }^{95}$ had been reserved originally for the rehabilitation of the stateless survivors gathered together under the rubric of Displaced Persons. In this context, a displaced person included former German survivors who were obviously not represented by a German state. Its redefinition of eligibility, however, meant that this Fund was primarily intended for Jewish persecutees, ${ }^{96}$ as Seymour Rubin emphasized shortly thereafter. ${ }^{97}$ In other words, those stateless (overwhelmingly non-Jewish) Displaced Persons who were the remnants of forced laborers brought to Germany during the war, and who did not return to their countries of origin, were not the focal point of this arrangement.

On the other hand, both groups, whatever the expected source of assistance, were from that point on the objects of public and private social welfare support. Although interest was limited, it was this support that engaged the Paris delegates, not the concept of compensation or restitution. In short, much of the early compensation efforts, including collective social welfare, took place in an international framework that saw the effort in terms of social welfare rather than compensation. The expected result of the special "external German-assets" collection effort, on the other hand, conceived as a way to assure a reasonable amount of reparations for the smaller Allies, foundered on the resistance of neutrals such as Switzerland. This postwar conflict between the Allies and the Swiss was an integral part of the reparations story, the significance of which would only be apparent later on. The failure to resolve that conflict in a politically satisfactory way bore indirectly on the reopening of victim-compensation

gees to enter Palestine .... The key to my successful negotiations were the Yugoslavs whom I sought out and who were acting as the leader of the Eastern bloc. Once they wereassured that $I$ had no intention of having any of the reparation money go to anti-Tito refugees, they were willing to go along with the U.S. proposals.

Id. at 75. Ginzberg's leading role in these repatriation discussions is confirmed in U.S. and Allied Efforts to Recover and Restore Gold and Other Assets Stolen or Hidden by Germany During World War II, U.S. State Department Preliminary Study, 10468, 91-96 (1997) [hereinafter USDS-I].

94. FRUS-II, supra note 32, at 1450.

95. Rubin \& Schwartz, supra note 87 , at 379 n.11.

96. On the other hand, it also was a brute fact that a very substantial portion of the nonrepatriable Displaced Persons (at least in the U.S. Zone) were Jewish. USDS-I, supra note 93, at 95. Thus, the redefinition did not so much ignore the non-Jewish Displaced Person's as narrow that small component to those who had suffered racial, religious, and political persecution rather than those who were held in wartime Germany or who made their way to the Western zones of Germany in the aftermath of the war.

97. Rubin \& Schwartz, supra note 87, at 379. 
issues with Swiss governmental and financial institutions, even in the $1990 \mathrm{~s} .{ }^{98}$

Presently, two other points are important to note. The first, necessarily implied in the above account, is that the redefinition of the stateless population brought with it, for the first time, the important distinction between forced (nonincarcerated) laborers and slave laborers. The second is to highlight the connection between this special fund and the efforts of the representatives of European Jewry to gain standing to claim these and possible later funds to help resettle the few survivors of wartime extermination programs, whether in Israel or in the Diaspora, and to help revive Jewish religious and communal institutions in the liberated regions.

\section{The Position of Jewish Organizations and the Jewish Agency of Palestine}

Representatives of Jewish organizations attended the Paris talks as observers, and were finally heard in early postwar Washington following the U.S. government's relative neglect of their voices and concerns during the prosecution of the war. On September 12, 1945, Nahum Goldmann, U.S. Representative of the Jewish Agency for Palestine, presented a letter from the Agency President, Dr. Chaim Weizmann, to Dean Acheson, Under Secretary of State, for consideration at the impending Paris meeting. ${ }^{99}$ It was the first formal presentation of its expectations "as the representative of the Jewish people."100 Excerpts from this document were important signs of the future relationship between this precursor to the State of Israel and the entire reparations and compensation regime of the future:

The first declaration of war by Germany ... was made against the Jewish people .... Its aim was ... the complete physical extermination of the Jews, the utter destruction of their spiritual and religious heritage, and the confiscation of all their material possessions .... This war against the Jews has created a three-fold problem - of reparation, of rehabilitation, and of restitution.

Of the surviving Jews of the European Continent, some may desire to settle in their countries of origin, and some to seek a new life in other countries of the Diaspora, but the vast majority desire to make their permanent home in Palestine. Such assets as may be recovered by way of indemnification ... for Property confiscated or destroyed, or deposited and rendered available by the extinction of ownership, for the several purposes of Jewish rehabilitation should be applied to all these tasks [of reparation, of rehabilitation, and of restitution]. In so far as they are applied to the settlement of Jews in Palestine, they should be placed under the trusteeship of the Jewish Agency for Palestine.

But the means likely to be derived from this source will fall far short of what is needed for the rehabilitation of Jews anxious to settle in Palestine. The main part

98. A separate presentation of these issues is planned for future publication. The most direct link, of course, lies in the fact that the Paris Agreement also called separately for the collection of non-monetary gold and heirless assets in neutral countries. Again, this primarily involved Switzerland, and, to a lesser extent, Sweden, Spain, and Portugal.

99. FRUS-III, supra note 41, at 1302-05.

100. Id. at 1302 . 
of the funds for this purpose should, in justice, be provided from the reparations due from the enemy states for the infinitude of murder, suffering and destruction which they have inflicted on the Jewish people....

It is therefore submitted that a proper percentage of the reparations to be obtained from Germany should be allotted for the purpose of the resettlement in Palestine of Jewish victims of racial and religious persecution, and granted, in the form of suitable assets (e.g., plant, machinery, equipment, and materials), to the Jewish Agency for Palestine, as the body charged by international authority with the duty of developing the Jewish National Home.

Weizmann's proposal was the product of two strands of contemporary discussion within Jewish circles. These discussions had begun, some private initiatives aside, ${ }^{102}$ in 1941 when the full scale of Nazi aims for the social and economic, if not yet physical, extermination of Jewish life in Europe became clear. ${ }^{103}$

At this time, the new Institute of Jewish Affairs of the World Jewish Congress developed a fact-finding program and an initial argument for direct compensation by postwar Germany for material losses. ${ }^{104}$ Under classic principles of public international law, this would have depended on each European state's representation of its Jewish subjects; in other words, these losses would have been part of an overall reparations demand. ${ }^{105}$ For the German Jews, the earliest group persecuted, this would have presented an anomalous situation in traditional interstate relations. ${ }^{106}$ This fact was recognized by those working on this issue, who understandably turned to other, newer concepts that would justify direct claims. At roughly the same time, Palestinian Jews who had been involved in the prewar negotiations with Third Reich agencies controlling capital transfers from Germany by German Jews immigrating to Palestine, began to work on future restitution issues. They recognized, according to Nana Sagi, three relevant factual situations and the institutional problem of their resolution:

[I]ndividual property for which claims could be made; individual heirless property; and property of Jewish communities and organizations that had been destroyed and for which it was not possible to make any claims. [Schreiber] also called attention to the fact that ... a Jewish organisation that could appear before the respective authorities as the official claimant of the Jewish people for its lost properties [had not] been established. ${ }^{107}$

The Palestinian Jews also appreciated and debated the question of representation and made clear distinctions between the losses suffered by Jewish (former) subjects of Germany and similar losses by individual victims and Jewish communal institutions in other countries. ${ }^{108}$ In particular, the issue of direct standing to

101. FRUS-III, supra note 41, at 1303-05, 1437.

102. NANA SAGI, GERMAN REPARATIONS: A History OF NegOtiations 14-15 (1980).

103. The following review relies heavily on the work of Nana Sagi. See SAGI, id. at 102

104. Id. at 21 .

105. See, e.g., Hugo MarX, The CASE of THE German Jews vS. Germany (1944).

106. SAGI, supra note 102 , at 16 (quoting comments made by Nahum Goldmann at that time); see also NAHUM GOLDMANN, AUTOBIOGRAPHY: SIXTY YEARS OF JEWISH LIFE 216 (1969).

107. SAGI, supra note 102 , at 16 .

108. SIEGFrIED MOSES, JEWISH POST-WAR ClaIMS 411 (Wolf-Dieter Barz ed., 2001) 
present claims involved a bitter irony due to the internally divisive role Jewish organizations played in the formulation of the specifically Jewish elements of the Minorities Treaties negotiated before and upon the conclusion of World War I. ${ }^{109}$ While reluctantly adopted and substantially failing in later implementation, ${ }^{110}$ these treaties, and some domestic legislation, accepted some guarantees of religious freedoms of worship, education, and partial civic autonomy in Czechoslovakia, Hungary, Poland, Romania, and Yugoslavia. ${ }^{111}$

These treaties provided both Jewish and linguistic-minority groups limited standing to report violations to the League of Nations committees. However, recourse to the permanent court's advisory and the obligatory jurisdiction was limited to states, including, as was essential for even rudimentary protection of state minorities, third states. ${ }^{112}$ Indeed, based on this mix of provisions and on the British Palestine Mandate, ${ }^{113}$ a considerable discussion ensued during the pre-1933 interwar years as to the status of the "Jewish people" (das jüdische Volk) as right- and duty-bearing subjects of public international law. 114

Nonetheless, Jewish organizations present at these conferences did not press for the addition of Jewish minority rights to the linguistic-minority rights Germany accepted in the Versailles Treaty. Imperial Germany had earlier been seen as a guarantor of Eastern (Russian) Jewish civil, political, and religious rights during World War I, so much so that this was a concern of the Allies be-

109. For a recent history of the intra-Jewish aspect of the Versailles-era negotiations, see MARK LEVENE, WAR, JEWS, AND THE NEW EUROPE 284-302 (1992).

110. For more about the Treaties and their minimal influence on the political developments during the interwar years, see JACOB ROBINSON ET AL., WERE THE MINORITIES TREATIES A FAILURE? (1943). A more optimistic but earlier assessment, emphasizing the relatively assertive role of the Permanent Court of International Justice, is given by HERSH LAUTERPACHT, THE DEVELOPMENT OF INTERNATIONAL LAW BY THE PERMANENT COURT OF INTERNATIONAL JUSTICE 72 (1934). For the current echo of this period, now at the regional rather than international level, see the review of similar controversies in Gaetano Pentassuglia, Minority Issues as a Challenge in the European Court of Human Rights: A Comparison with the Case Law of the United Nations Human Rights Committee, 46 GERMAN YB INT'L L. 401 (2004).

111. See Manley O. Hudson, The Permanent Court of InTernational Justice 19201942 , at 440-41 (1943).

112. For a contemporaneous review of the sparse case law, see Nathan Feinberg, La Juridiction et la Jurisprudence de la Cour Permanente de Justice Internationale en Matière de Mandats et de Minorités, 59 REC. CoUR 587 (1937). Especially interesting is a case most analogous to Jewish issues, Minority Schools in Albania, 1935 P.C.I.J. (ser. A/B) No. 64, requiring absolute rather than only national treatment of Greek Christian schools in Albania after the latter closed all private schools.

113. For a general overview of this Mandate, see DAVID FROMKIN, A PEACE TO END ALL Peace: The fall of the OtToman Empire and the CREation of the Modern Middle East (2001).

114. Compare Hugo Wintgens, Der völkerrechtliche Schutz der nationalen, sprachlichen, und religiösen Minderheiten, in II:8 HANDBUCH DES VÖLKERRECHTS 279 (1930) with GEORG LANDAUER, DAS GELTENDE JÜDISCHE MINDERHEITENRECHT MIT BESONDERER BERÜCKSICHTIGUNG OSTEUROPAS 54 (1924). Wintgens describes this as the first debatable instance of this extension in classic public international law; thus, we might indeed trace the Weizmann proposal directly and not only symbolically back to the Versailles context. Not surprisingly, this congeries of issues has come again to the attention of contemporary writers. For both her own treatment and her review of other recent works, see CAROL WEISBROD, EMBLEMS OF PLURALISM 119-37 (2002). 
fore the United States entered the war. ${ }^{115}$ Under the circumstances, German Jewish political organizations saw no reason to accept the "stigma" of minority classification in Germany. ${ }^{116}$ It probably would have made no difference in the end, ${ }^{117}$ just as, in the converse situation, the imposition of the bitterly resented Minorities Treaties in countries that later were Axis members did not seem to affect whatever limited protection they offered their Jewish subjects against Nazi deportation and extermination programs. ${ }^{118}$ The only case in which treatybased protection made even a temporary difference was Upper Silesia. Articles 66-72 of the May 1922 post-plebiscite Agreement between Germany and Poland concerning the German region, copied from the relevant Articles 1, 2, and 7-12 of the analogous protective provisions of the 1919 Allied-Polish Minorities Treaty, protected Silesian Jews from measures of discrimination based on religion. 119 Only after the expiration of that Agreement in 1937 did the racial measures of the German Reich become applicable to Silesian Jews. ${ }^{120}$

In any event, these issues depended upon a new approach that Siegfried Moses, a leading figure in the Association of Central European Immigrants in

115. See LEVENE, supra note 109 , at 175-76.

116. Responding to reports that a German Jew had appealed to the League of Nations in 1933 to challenge the initial discriminatory legislation of the new National Socialist regime, the President of the League of Jewish Combat Veterans [Reichsbund Jüdischer Frontsoldaten] wrote the Chancellor, Hitler, assuring him that:

in the name of the Jewish combat veterans I reject, with the utmost sharpness, any solution of Jewish questions that might lead us out of the society [Verband] of the German nation. I raise particular objection to the involving of foreign political groups in the handling of inner-German Jewish questions.

Letter of Bundesvorsitzender Löwenstein, May 23, 1933, reproduced in KLAUS J. HERRMANN, DAS DRITTE REICH UND DIE DEUTSCH-JÜDISCHEN ORGANISATIONEN 1933-1934, 156 (1969); see also Marcus Funk et al., Was It All Just a Dream? German-Jewish Veterans and the Confrontation with Volkisch Nationalism in the Interwar Period, in SACRIFICE AND NATIONAL BELONGING IN TWENTIETH-CENTURY GERMANY (2002) (providing a sense of the context in which this response should be understood).

117. For succinct current overviews of the fate of this entire effort at Versailles, see Capotorti, Minorities, in ENCYClOPEDIa OF PUBLIC INTERNATIONAL LAW 410 (Bernhardt ed., 1997) PATRICK THORNBERRY, INTERNATIONAL LAW AND THE RIGHTS OF MINORITIES 38-54 (1991).

118. The important cases to examine from this perspective would be those of Hungary and Romania, as nominally independent Axis members. See RAUl HILBERG, THE DeSTRUCTION OF THE EUROPEAN JEWS 485, 509 (1985) (providing a classic overview of both countries' experiences). On Romania, see THE DESTRUCTION OF ROMANIAN AND UKRAINIAN JEWS DURING THE ANTONESCU ERA (Randolph L. Braham ed., 1997); Irina Livezeanu, The Romanian Holocaust: Family Quarrels, 16 E. EUR. POL. \& SOC'YS 934 (2003). On Hungary, see generally RANDOLPH L. BRAHAM, THE POLITICS OF GENOCIDE: THE HOLOCAUST IN HUNGARY (1994). Bulgaria's is a different story, since the Holocaust did not rage there. See Frederick B. ChARY, THE BULgarian Jews AND THE Final SOLUTION, 1940-1944 (1972).

119. 16 Martens Nouveau Recueil (ser. 3), 668-73.

120. On the complaint of one of these German-Silesian subjects, Franz Bernheim, an ad-hoc Legal Committee of the League Council recommended acceptance of his argument that the application of the new racial legislation of Germany in Upper Silesia violated his treaty rights. This resulted in a formal finding of violation (and a remit to assess damages) against Germany at the June 6,1933 session of the League Council. The two German statutes bracketing this period, Law of June 11, 1922, RGBl. II at 237, and Law of June 30, 1937, RGBI I. at 717, are briefly discussed in "Die Sonderstellung der Juden in Oberschlesien Zwischen 1933 und 1937," I Gutachten des Instituts für Zeitgeschichte 87 (1958). 
Palestine, developed. His political views, gathered in a recently reprinted 1944 publication, ${ }^{121}$ adumbrated almost all of the issues that were aired during the early postwar years and that culminated in the Luxembourg Agreement of 1951. A postwar student's review of his role makes this clear:

Indeed, the crystallization of postwar Jewish claims owed much to this booklet, which covered all the most important features of the claim submitted eight years later by the State of Israel: the Jewish claim as an innovation in international law; the collective claim regarding heirless Jewish property and in respect of the damage inflicted on the Jewish people; payment of compensation by Germany in the form of commodities for the development of Palestine; [and] the establishment of a Jewish umbrella organization to represent world Jewry in its claims for reparation from Germany.

Most significantly, Moses argued that for both heirless and communal claims, the Jewish Agency representing the Jewish community of Palestine was the appropriate international organization to present claims. ${ }^{123}$ This publication "played no small part in encouraging Dr. Weizmann to present the Allies with the [September] 1945 statement of Jewish claims." 124 Moreover, his book helped to clarify the position of Jewish survivors as a subset within the group of Displaced Persons. It also helped obtain the Conference's creation of the (inadequate) separate fund for their rehabilitation, thus legitimating the connection between rehabilitation and migration to Palestine. ${ }^{125}$

The issues concerning the support of Jewish survivors returning to their home countries or emigrating to countries other than Palestine, and the separate issue of supporting the reconstruction of Jewish religious and communal organizational life in the Diaspora, was emphasized in a parallel program carried out by the Institute of Jewish Affairs under the leadership of Dr. Nehemiah Robinson. ${ }^{126}$ This approach, along with that of Siegfried Moses and an additional project commissioned by the Jewish Agency in 1943 and presented to its Executive in April of $1945,{ }^{127}$ comprise the essence of the Weizmann Proposal.

121. MOSES, supra note 108 , at 7-80 (summarizing the proposed approaches). For background on Moses, see the introduction of the work. Id. at xvii (Heuberger's Bio-bibliographic Appreciation Section).

122. SAGI, supra note 102 , at 20.

123. MOSES, supra note 108 , at 80 .

124. SAGI, supra note 102, at 20 (citing the oral history of Gershon Avner, Secretary of the Government of Israel's Delegation to the 1950 Oudkasteel Conference that led to the Luxembourg Agreement between Israel and the Federal Republic of Germany).

125. One other aspect of this interwar history as it bore on legitimating the Jewish Agency for Palestine as representative of its Jewish community, however, also should at least be mentioned: its role in working with the early (i.e., pro-emigration) National Socialist regime to establish the financial basis of Jewish emigration from Germany to Palestine--the Haavara Transfer scheme. For a full review, see SAGI, supra note 102, at 16; WERNER FEILCHENFELD ET AL., HAAVARA-TRANSFER NACH PALÄSTINA (1972).

126. See generally NEHEMIAH ROBINSON, INDEMNIFICATION AND REPARATIONS - JEWISH ASPECTS (1944). This program was a notable exception to the otherwise modest public demands of U.S. Jewish organizations; see the critical comments to that history in Schalom Adler-Rutel, Aus der Vorzeit der kollektiven Wiedergutmachung, in ZWEI WELTEN [FESTSCHRIFT SIEGFRIED MOSES] 200, 209 (Hans Tramer ed., 1962).

127. SAGI, supra note 102, at 26-27. 
Thus, these early initiatives indirectly but clearly laid the foundation for the eventual structure of the Luxembourg Agreement between Germany and Israel, and its pendent Protocol with the new Diaspora umbrella organization, the Conference on Jewish Material Claims Against Germany. ${ }^{128}$ While Weizmann only represented the Jewish Agency for Palestine, ${ }^{129}$ the U.S. delegation's simultaneous presentation of the Displaced Persons program in Paris brought these two strands into a common political discourse.

III.

\section{THE PARIS REPARATIONS AGREEMENT}

From the issues of individual expectations and stateless person claims we now return to the chronology of events and disputes that the Paris Treaty engendered. The formal conclusion of the Paris Agreement depended on a number of remaining issues: the horse-trading of allocation shares, the assignment of separate reparations expected from the lesser Axis Powers to those Allies that had been occupied or otherwise detrimentally affected by the former, the final drafting of the earlier-reviewed institutional mechanism that ensured retention of real power over reparations and their allocation to the Occupation Powers, and finally, the (incomplete) specification of the procedures for pursuing German assets in neutral countries for both the Stateless and Displaced Persons and some of the Allies.

The Paris Agreement established three separate reparation tracks. ${ }^{130}$ First, specific assets found in the Western Zones of Germany were subject to return to any signatory country that could prove that it or its subjects had had a significant financial interest in either the particular asset or group of similar fungible assets. These returned assets would be charged against that country's percentage allocation of real assets (or their monetary value if liquidated) granted under the agreement.

The allocation of non-restitutable assets comprised the second track, and consisted of two types of assets. One, category (B), was industrial (productive capital) equipment taken from Germany, as well as German merchant ships and inland water transport, all under the decision-making authority of the IARA that was itself subject to the actual asset removal determinations of the Allied Control Council. The other, category (A), consisted of all other assets, the principal component of which was German external assets located in neutral and signatory Allied countries. This category also included dwindling and eventually il-

128. Luxembourg Treaty with attached Protocol on Jewish Claims, Sept. 10, 1952, 162 U.N.T.S. 205 (1952).

129. Weizmann did so at a time when the possible creation of the State of Israel still was vigorously opposed by the United Kingdom. See generally ChaIM WeIZMANN, TRIAL AND ERROR: THE AUTOBIOGRAPHY OF CHAIM WEIZMANN (1949).

130. Paris Reparations Agreement, supra note 16, at 3191. It was in the form of an Executive Agreement, a point that recently became a major pillar of the majority opinion in American Insurance Association v. Garamendi, 539 U.S. 396, 403 (2003); see also LAWRENCE MARGOLIS, EXECUTIVE AgREEMENTS AND PRESIDENTIAL POWER IN FOREIGN POLICY 15-16 (1986). 
lusory assets such as deliveries from the Soviet Zone to the West. ${ }^{131}$ At one point, the United Kingdom argued that the value of forced labor by German prisoners of war held after the termination of hostilities should also be included as a debit against the benefiting country's allocation; this focused primarily on France, which claimed the right to require this service, and exercised it until 1947. ${ }^{132}$ Not surprisingly, a bitter and sensitive political battle erupted over this proposal, and the United States finally sided with France in rejecting this category, though under the condition that they hasten repatriation of these prisoners of war and that they be exempt from performing any dangerous service such as mine clearing. ${ }^{133}$ Finally, it is important to recall that, of the above outlined German external assets, $\$ 25,000,000$ was set aside to support the stateless victims of Nazism. The third track involved gold looted by or wrongfully removed from the occupied countries by Germany during the war.

Finally, the Axis members and co-belligerent Finland were to pay some reparations, but only to specific victim-states, pursuant to the Peace Treaties that the Paris Agreement anticipated. The treaties were signed in 1947 by Bulgaria, Finland, Hungary, Italy, and Romania. Austria, which came into the enjoyment of victim status for reasons not immediately obvious, is a different story. Its Treaty of Peace was signed in 1955, when its unique quasi-occupation status by the Western Allies and the Soviet Union ended, and did not require it to make general reparation payments (as distinguished from restitution of identifiable property found there after the war). ${ }^{134}$

Thus, from January 1946 to mid-1949, three collection efforts took center stage. The first process implemented the smaller Western Allies' effort to collect their share of reparations. In particular, searching for identifiable assets located in the Western Zones to which a plausible claim of direct restitution could be made. The second involved the search for German monetary gold ${ }^{135}$ looted by German occupation forces, which was to be shared by all Allies under the monetary-pool arrangement. ${ }^{136}$ The above efforts were also intended to imple-

131. Paris Reparation Agreement, supra note 16, at 3157.

132. FRUS-III, supra note 41, at 1382-83; see also Treaty of Peace with Bulgaria, Feb. 10, 1947, art. 26, 61 Stat. (2), 41 U.N.T.S. 21; Treaty of Peace with Hungary, Feb. 10, 1947, art. 30, 61 Stat. (2) 2065, 41 U.N.T.S. 135; Treaty of Peace with Italy, Feb. 10, 1947, art. 77, 61 Stat. (2), 49 U.N.T.S. 3; Treaty of Peace with Romania, Feb. 10, 1947, art. 28, 61 Stat. (2) 1757, 42 U.N.T.S. 3.

133. For an account of the retention of German POWs in France and the relatively late date of their release, see Kurt Willi Boehme \& Horst Wagenblass, Die deutschen Kriegsgefangenen in französischer Hand, in 13 ZUR GESCHICHTE DER DEUTSCHEN KRIEGSGEFANGENEN DES ZWEITEN WELTKRIEGES (Erich Maschke ed., 1971).

134. For a review of Austrian compensation of its own persecuted subjects, including the recent legislation enacted in consequence of United States-Austrian negotiations, see Eric Rosand, Confronting the Nazi Past at the End of the 20 th Century: The Austrian Model, 20 BERKELEY J. INT'L L. 202 (2002).

135. For a definition of this category, see the Paris Reparations Agreement, supra note 16.

136. The related search for non-monetary gold and similar valuables (so-called victims' gold) belongs to the implementation story and thus to later review. The disposition of German private sector assets, whether located in Allied countries and frozen there by wartime legislation, or frozen in neutral countries under similar legislation, is also a separate issue, though it overlaps to some degree with the searches called for by the Paris Agreement. 
ment the promise to support the redefined Displaced Persons communities through the collection of assets that, as categories, coincided with those being sought by the smaller Allies as reparations. Third, there was an effort to procure German private-sector assets in neutral and Allied countries.

The fruits of those efforts were an important prelude to the next stage of the postwar story - the expansion of reparations, restitution, and compensation claims to encompass private claimants, and the resolution of prewar debt claims and postwar state occupation-cost claims. In a subsequent article I provide the separate treatment this issue requires. There I argue that the emphasis on settling prewar debts of the Reich to foreign creditors led to the absolute ban on state as well as private claimants' further efforts to achieve payment of reparations and compensation. The removal of the litigation barrier after the unification of Germany in 1990 revived the efforts of private claimants ${ }^{137}$ to achieve their long-deferred compensation for old losses in the entirely new political and legal climate of the 1990 s.

\section{CONCLUSION}

This article reviewed the legal and political nature of the ground rules the Allied Occupation Powers created to serve as the underlying basis for the actual effort to collect reparations. The implementation of those rules during the period before both East and West Germany regained sovereign status in 1949 is by and large anticlimactic. The major powers took what they wished, although somewhat constrained, especially with regard to the United States, whose view of the repercussions of reparations overshadowed other powers' considerations. The formerly occupied Allied governments (other than France) ${ }^{138}$ searched for identifiable and restitutable assets, ${ }^{139}$ while pursuing their increasingly frustrated hopes of participation in the reparations allocations of German and Axis public and private property. This aim was further frustrated in increasing degree by the policies of the United States.

The narrative of the Paris Agreement's implementation is accompanied by a different component of interstate reparation claims. It began in 1950, when the major Allies' claims to reimbursement of their postwar expenditures, and the perceived need to resolve Germany's prewar public debts to its lenders, led to the London Debt Agreement of 1953. The 1953 Agreement not only brought in

137. The reparations claims of states unsatisfied at the time of the London Debt Agreement were largely satisfied by a number of bilateral reparations agreements the Federal Republic of Germany, in the healthier economic climate of the 1960 s, entered into during that decade.

138. Standing marginally under their governments' umbrellas, some private parties did so as well.

139. A particularly good example is that of the Government of the Netherlands seeking to increase its allocative share of the gold pool by claiming full restitution (or equivalent compensation) of ingots looted by German occupation forces and transferred to Italy as a result of wartime transactions with Germany and Sweden, respectively, under the Italian Peace Treaty. The claim was rejected, and the Netherlands limited to its share of the pool. See The Case Concerning Gold Looted from the Netherlands, 44 I.L.R. 448 (Decision of the Italy-Netherlands Conciliation Commission of August 17, 1963) (1972). 
its wake yet another era of interstate reparations, but also a set of bilateral (West) German treaties with each state that raised such claims. Interstate reparations stretched through another decade, and were followed in the 1970 s by new interstate discussions with the socialist countries of Central Europe.

More importantly, however, the 1953 Agreement also set the stage for four decades of instability between Germany and the millions of victims seeking compensation for the wrongs inflicted on their person and property during the reign of the Third Reich. A variety of confrontations and negotiations persisted throughout those years, taking a sharp turn with the unification of Germany in 1990 , but only after the litigation of the 1990s and the creation of the described foundation did some sense of closure arrive. 140

140. Indeed, this Agreement has now become one building block leading to the majority opinion in American Insurance Association v. Garamendi, 539 U.S. 396, 403-05 (2003); see also Brannon P. Denning \& Michael D. Ramsey, American Insurance Association v. Garamendi and Executive Preemption in Foreign Affairs, 48 WM. \& MARY L. REV. 825 (2004). 